（45）変圧器用兔震スライド装置の実証試医と免震挙動の分析

\begin{tabular}{ll} 
東京電力 (株) & \multicolumn{2}{c}{ 高橋由多加 } \\
東京電力 (株) & 山本 康博 \\
東京電力 (株) & 堀口 潤一 \\
日本工営 (株) & 真柴 純治
\end{tabular}

1.まえがき

近年, 重要設備の耐震安全性向上の一手法として「免震システム」に着目した研究例, 適用例が增えてき ている。筆者等は電力設備の中で震害事例のある変電設備のうち, 変圧器を対象とした免震装置の開発を昭 和56年から進めており，現在までに変圧器の特性を考虑して開発した「免震スライド装置」について，模型 振動実験，数値解析，実証試験等によって，その免震効果の確証を行ってきた。今回は，免震スライド装置 で支持した実変圧器の地震観测によって得られた実証試験結果について報告するものである。

2. 実証試験概要

図-1下実証試験に用いた免 震スライド装置の基本構造を, 写真一 1に構成部品を示す。装 置は上沓, 下沓,ベアリングプ レート, 復元ラバーで構成され ており, 次のような特徵がある。

（1）変圧器荷重は上沓, ベ

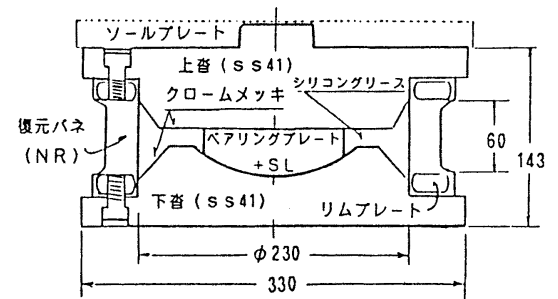

図-1＼cjkstart兔震スライド装置の基本構造

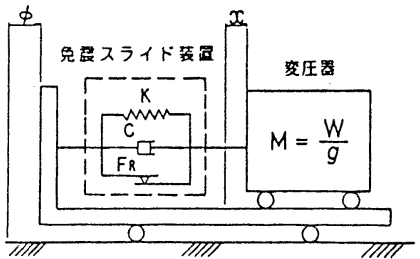

図一2 力学モデル

アリングプレート,下沓 で支持し, 復元ラバーに は荷重負担がかからない

（2）同上理由より，重荷重 の支持に適しているとと もに, 復元ラバーによる 変圧器のロッキングの誘 発は生じない。

（3）構造が軸対象であり, 水平面内のあらゆる方向 に対して同等の挙動を示す。

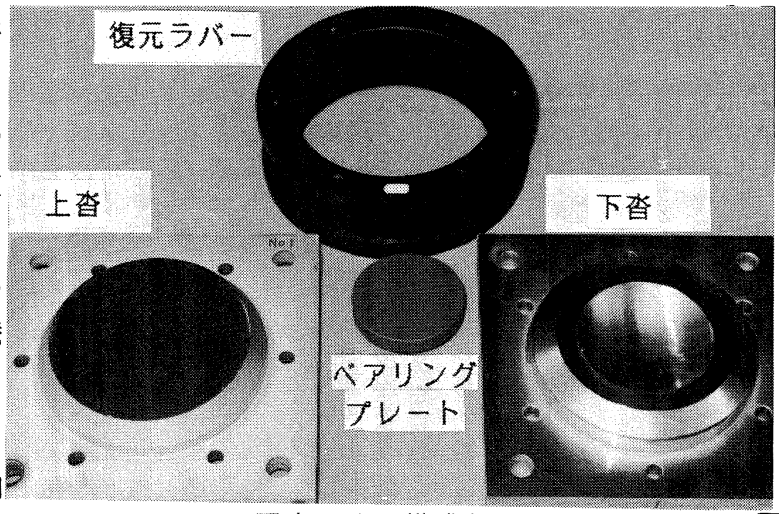

写真 -1 構成部品

(4) ベアリングプレート下面は球面加工してあり, スライド面に生じる面圧を 均一に分布させる。

(5) 形状規模がコンパクトである。

この装置を簡単な力学モデルで示すと図一2のようになり,バネ、ダンパー とともに摩擦が並列に組み合わされている。そのため, 図一3の作動状況に示 すとおり，入力する加速度レベルが大きくなり変圧器に作用する慣性力が摩憏 カを越えた時に上沓とベアリングプレートの間がスライドし装が作動する。

実証試跧の内容を表一 1 に示す。実証試験は昭和59年 9 月から栃木県小山市 にある当社小川変電所にて継続している。対象とした変圧器は容量 $105,000 \mathrm{KVA}$ 重量235tonf であり,クーラーと防音カバーは取りはずした状態である。

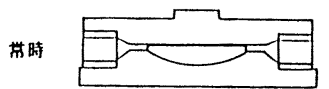

地玨时

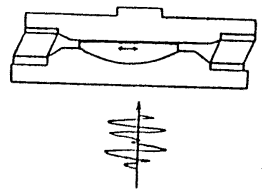

证-3作動犾㫛 表-1 実証試験内容

\begin{tabular}{|c|c|}
\hline 目 & 内 谷 \\
\hline 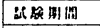 & 59年 9月～61年3月（予定） \\
\hline 践触所 & 的木支店小山変䨤所娟内 \\
\hline 对每要压器 & 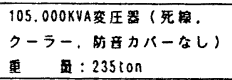 \\
\hline $\begin{array}{l}\text { 兔震スライ } \\
\text { ド蜝 }\end{array}$ & 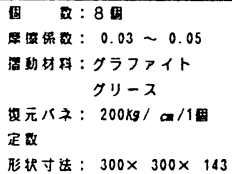 \\
\hline 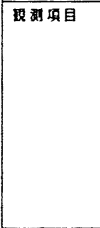 & 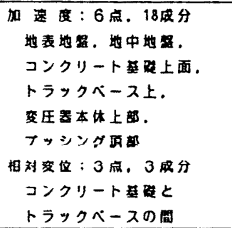 \\
\hline
\end{tabular}


圀-4および写真 $-2,3$ 下地震観测用の 計器配置と実訨試験状況を示す。免震対象と した変圧器は8個の免震スライド装置でコン总 クリート基礎上に支持されている。装置はな るべく小さな地震動でも作動するように，摺 動材料としてグラファイトグリースを使用し 摩䏅係数を極力押えてある。

計測計器は変圧器本体およびその周辺にサ 一ボ型加速度計を 6 点18成分, 免震スライド

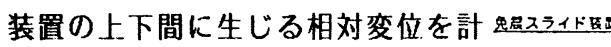
测する差動トランス型相対変位計を 3 点 3 成分の眍置としている。記録 の収録は約100離れた変電所本館内 でディジタル式データレコーダー （SAMTAC-85, 16bit）を用いて行っ

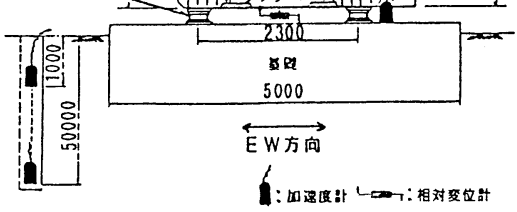
図-4計器配置

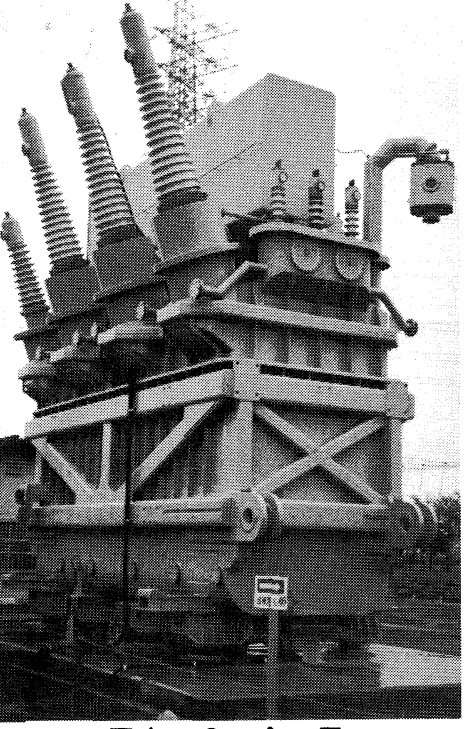

写真 -2 全 景

図一 5 地質柱状図

ている。

図一 5 に小山変電所地点の地質柱 状図を示す。この地点は地表部G. L. $-0.9 \mathrm{~m}$ までが盛土であり, それ以深 G. L. - 35. 5mまでは砂, シルト, 粘土 が互層となっている。N值はシルト 層および粘土層がほほ10以下，砂層 では10～50であり変化が大きい。ま たG. L. - 35. 5 m以深は砂浟層または砂

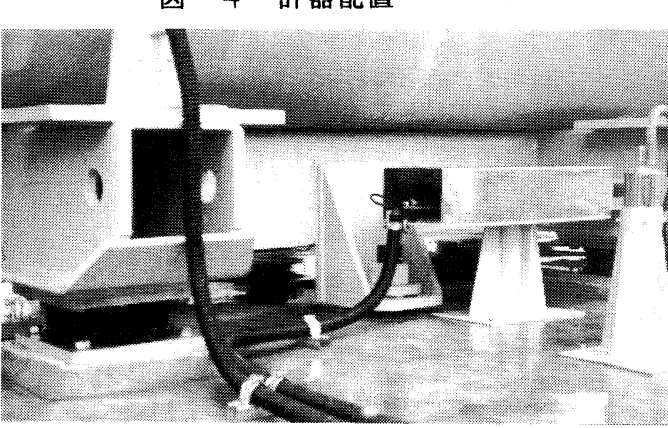

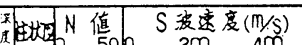
層となっておりN值50以上と締っている。S波速度はG. L. - -35.5mまでは 100〜 290 m/s であり,それ以深は 385〜 510m/sと大きな値を示している。

\section{3. 観測記録と免震挙動}

昭和60年 3 月 20 日, 茨城県南西部に発生した地震により地表で $173 \mathrm{gal}$ の加速度 記録が観测され，免震スライド装置の作動が確認された。その他にも約20回の地震記録が得られているが， 加速度レベルが小さく兔震スライド装置は作動していない。

表一 2 に観測地震の諸元を示す。マグニチュードは 4.9 , 震源深さ $60 \mathrm{~km}$ ，小山地点までの震央距離は約 22 kmである。

図一6，7 地表の加速度波形とそのフーリエスペクトルを示す。これらの図より，震央距離が小さく，

\begin{tabular}{|c|c|}
\hline 䇥生作月日 & 红租 60作 3月20日14洔 534\} \\
\hline 罪源地 & 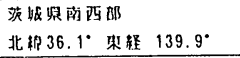 \\
\hline $\begin{array}{l}\text { マダ=チュ } \\
\text {-ド }\end{array}$ & 4.9 \\
\hline 毁源㳭さ & $60 \mathrm{~km}$ \\
\hline 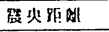 & $22 \mathrm{~km}$ \\
\hline 各地の酸度 & 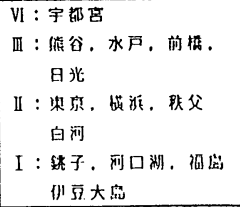 \\
\hline
\end{tabular}

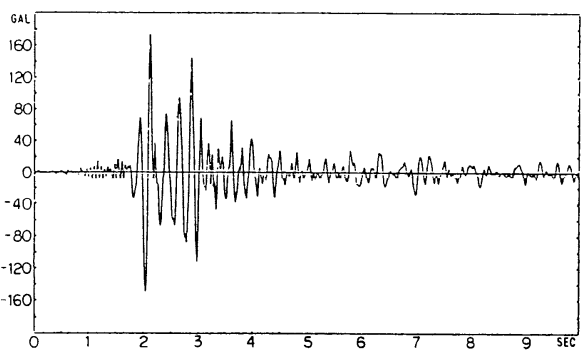

図-6 地表の加速度波形 (G.L. -1m, NS方向)

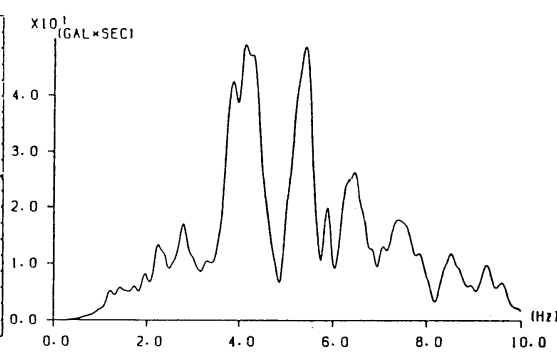

図- 7 地表加速度波形の

フーリエスペクトル 
内陸部に発生した地震動の特徵が次のように表現されている。

(1) 加速度レベルが他と比べて大きい主要動と見なされる部分が 約 1 秒程度であり非常に短い。

(2) マグニチュードが 4.9 と小さいのに対して最大加速度は173 gal と大きい。

（3）振動数成分は $4 \sim 6 \mathrm{~Hz}$ が卓越しており, 地盤特性から予想さ れる 1.4HZ程度の振動数成分はあまり目立たない。

図一8に観測波形のうち兔震スライド装置の上下の記録である コンクリート基礎上面と変圧器下端の加速度波形，並びに免震入 ライド装置に生じた相対変位波形を示す。この図より, 本装置の 作動の特徵が次のように認められる。

(1) 加速度レベルの大きい $2 \sim 3$ 秒付近では変圧器下端の波形が コンクリート基礎上面より小さくなっており, 加速度の低隇奻 果が見られる。

（2）それと同時に相対変位が生じている。

(3) 加速度レベルが30gal 程度以下の 4 秒以降においては相対変 位波形が示すとおり免震スライド装置は作動しておらず，加速 度波形も装置の上下で同一である。

(4) 最終的に相対変位が若干残留している。
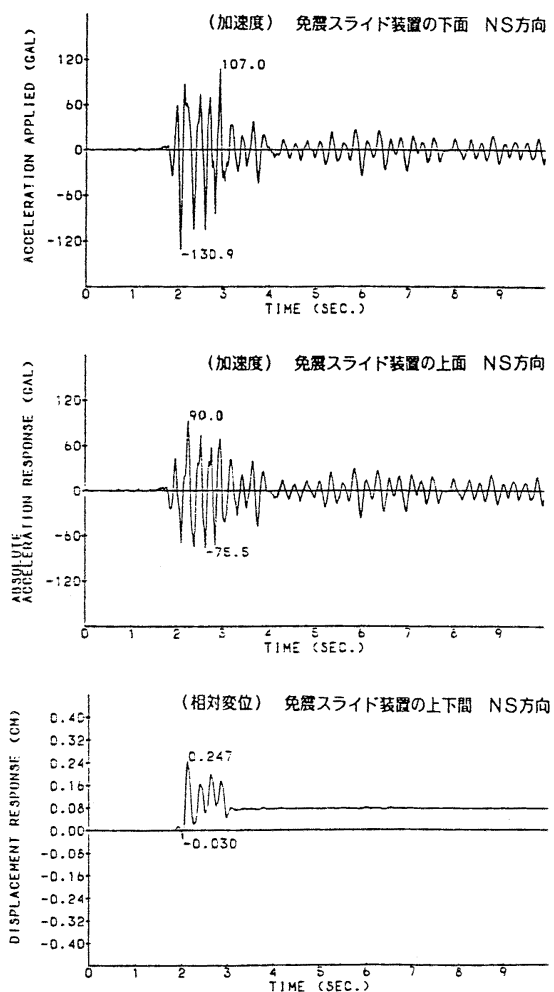

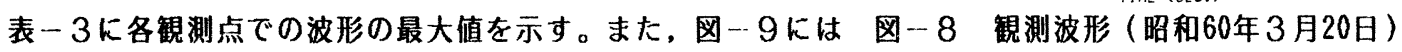
NS 方向の各観測点間のフーリエスペクトル比を示す。 これらの図表より地震時挙動が次のように理解される。

（1）基盤(G. L. -50 m)から地表（G.L. - 1m）への伝達特性は, 地然の持つ卓越振動数が頙著に現われている。その1次

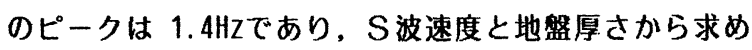
た值とほほ一致する。

（2）地表とコンクリート基礎のスペクトル比は $3.5 \mathrm{~Hz}$ 程度 にピークを持ち，地盤バネと基礎および変圧器質量より 定められる固有周期であろうと考。 えられる。また 4 HZ以上ではスペ クトル比が 1 より小くなる傾向 があり入力損失が見られる。これ， と対応して最大加速度値も173gal から141galに低減している。
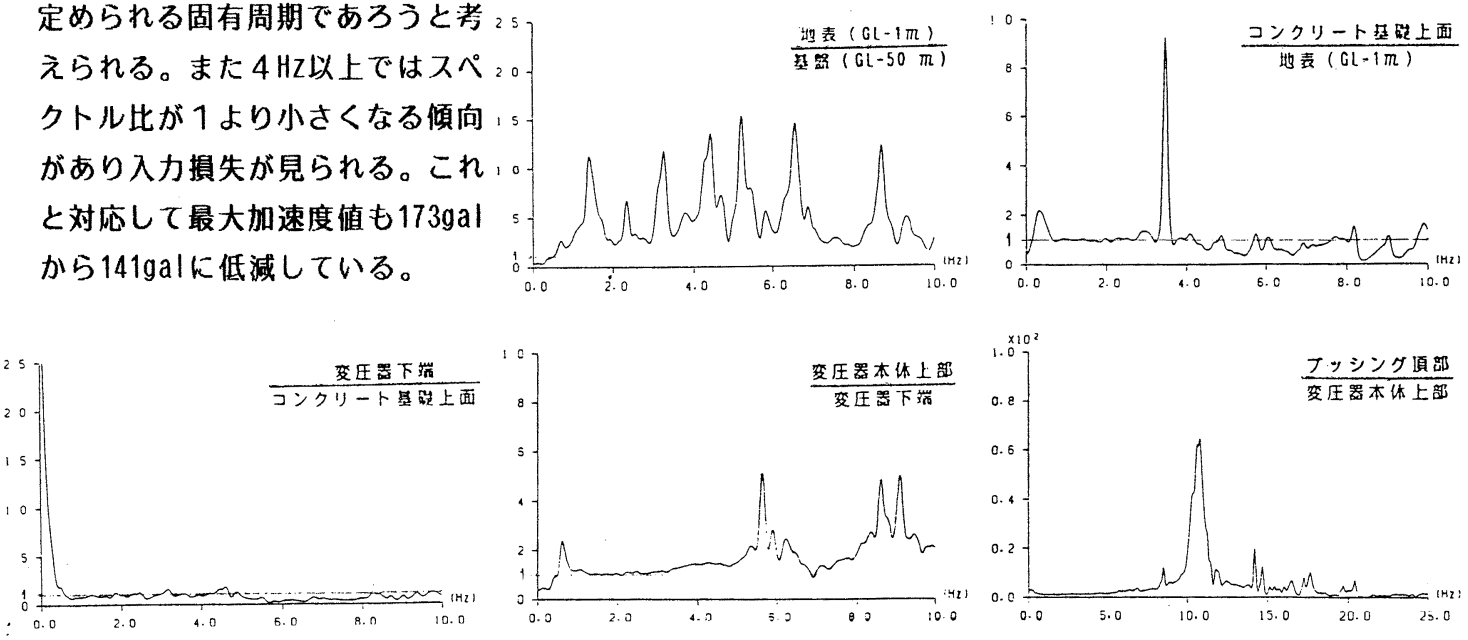

図--9 各観測点間のフーリエスペクトル比 
（3）免震スライド装置の上下（コンクリート基礎上面と変圧器下端）では, 水平面内の最大加速度值がNS 方向で131 gal から90gal に，EW方向で134galから101galにそれぞれ3割程度低隇している。最終的に 相対変位が残留していることと関連して,フーリエスペクトル比は低振動数側で大きくなっている。

(4) 変圧器下端と変圧器本体上部のフーリエスペクトル比より変圧器本体は $5.5 \mathrm{~Hz}$ 程度の固有周期を持つも のと想定される。

(5) 変圧器本体上部とブッシング頂部のフーリエスペクトル比はブッシングの固有周期と見られる11Hzでの 增幅が大きく，最大加速度值もブッシング頂部では543galと大きな值になっている。

\section{4. 免震挙動の数值計算}

免震挙動を数値計算により再現するとともに免震スライド装置の機能について若干考察する。計算モデル は図ー2に示した1質点系のモデルであり，コンクリート基礶上面の加速度波形を入力波とし，計算結果の 比較は変圧器下端の加速度波形および相対変位波形とした。基本方程式は次のとおりである。

$|M(\ddot{X}+\ddot{\phi})+C \dot{x}+K x|>F r$ のとき $M \ddot{x}+C \dot{x}+K x+\operatorname{sign}(\dot{x}) \cdot F r=-M \dddot{\phi}$ $|M(\ddot{X}+\ddot{\phi})+C \dot{x}+K x| \leqq F r$ かつ $\dot{X}=0$ のとき $M \ddot{x}=0$

$M$ : 変圧器の質量, $\ddot{X}:$ 相対加速度, $\ddot{\phi}:$ 入力加速度, $C:$ 減衰係数, $\dot{X}:$ 相対速度 $\mathrm{K}:$ バネ定数, $\mathrm{X}$ : 相対変位, $\mathrm{Fr}(=\mu \mathrm{Mg})$ : 摩摖力, $\mu:$ 摩摖係数, $\mathrm{g}:$ 重力加速度

表一 4 に入力定数值を示す。

隇衰係数 Cについてはトライアル計算を行い，此較的再現性の よい値を用いた。この值は減衰定数 hで表現すると $400 \%$ を越え る非常に大きい值である。これは摺動材料に用いたグラファイト グリースを畒内に充填させたため, スラィド面内のグリースが 摩摖係数の低下には寄与したものの粘性抵抗を増加させる作用を したものと考えられる。減衰係数は $\mathrm{C}=580$ tonf $\cdot \mathrm{sec} / \mathrm{m}$ 程度で あり,この值を用いた計算結果を図一10に示す。なお現在，粘性 抵抗試験を実施しておりC值の確㒛を行っている。

また，揌動材料としてグラファイトだけを用いた場合は，昭和 58年に実施した模型振動実験で減衰係数は C $=3.7$ tonf $・ \mathrm{sec} / \mathrm{m}$ 程度であることが確認されており，この場合は図ー11に示すよう に変圧器の応答がさらに低隇するものと予想される。

5.あとがき

今回の実証試験記録から免霞スライド装置の作動を確謵するこ とができた。それとともに実変圧器の免震挙動をある程度分析で きたと思われる。今後，粘性抵抗試䤅の結果を反映させた数値計 算を行うとともに，地盤のバネによる变圧器のロッキング挙動を 考虑した解析を行ない,フッシングを含めた変圧器各部位に対す る免震スライド装置の効果を評価したいと考えている。

(参考文献)

（1）堀口，山本，橋本：変電機器の免震スライド装置に関する研 究, 電力土木, N0.190, 1984.5

（2）橋本，堀口，山本，真柴：復元力を有するすべり支承の免覀 性能について, 土木学会第39回年次学術講演会概要集, 第 1 部 1984.10

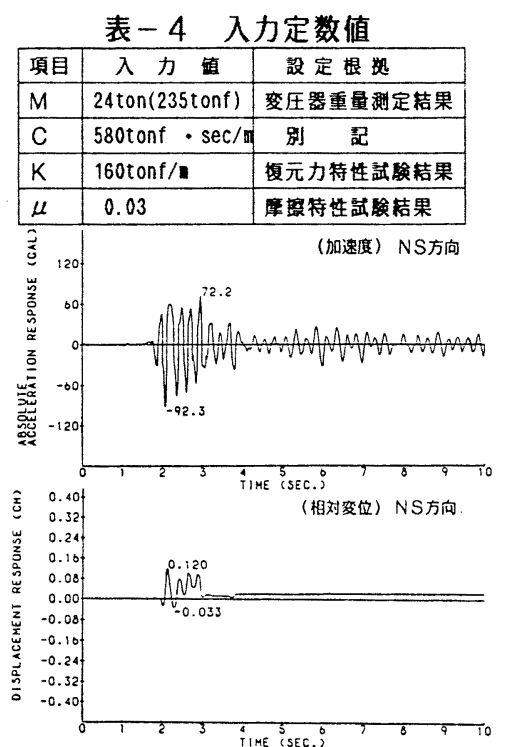

図-10 数值計算結果 $(\mathrm{C}=580$ tonf $\cdot \mathrm{sec} / \mathrm{n})$

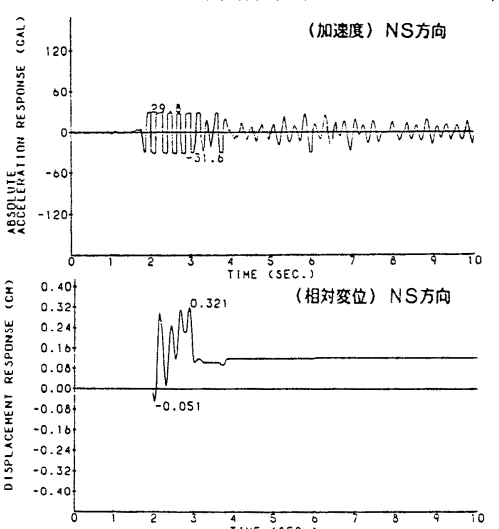

図-11数值計算結果 $(\mathrm{C}=3.7$ tonf $\cdot \mathrm{sec} / \mathrm{m})$ 